ARTICLES

\author{
Lassi Jakola \\ lassi.jakola@iki.fi
}

\title{
Wittgenstein and G. H. von Wright's path to The Varieties of Goodness (1963)
}

\section{Abstract}

This essay traces the development of Georg Henrik von Wright's (1916-2003) work in the theory of values from the early 1950s to the publication of The Varieties of Goodness (1963), with special focus on the influences stemming from Ludwig Wittgenstein's (1889-1951) later thought. In 1952, von Wright published an essay suggesting a formal analysis of the concept of value. This attempt was soon abandoned. The change of approach took place at the time von Wright started his work on Wittgenstein's Nachlass. This preoccupation with Wittgenstein led to a new approach to value judgments in 1954, with strong lateWittgensteinian influences on methodical as well as stylistic levels. Some important traces of the 1954 approach are still visible in The Varieties of Goodness, while the stylistic imitations and allusions have mostly been dropped. But in the late 1950s, new connections to Wittgenstein's later thought emerge: an aim to provide a "surveyable (re)presentation" (cf. PI: \$122) of the varieties of goodness, i.e. the various different but interrelated uses of the word "good" in language and an aspiration to make analytical philosophy something more than a "collection of material for academic controversy".

\section{Wittgensteinian influences in $G$. $H$. von Wright's philosophy? - An historico-genealogical case study}

Georg Henrik von Wright (1916-2003) attended Ludwig Wittgenstein's (1889-1951) lectures in 1939 and 1947 and was his immediate heir as professor at Cambridge between 1948 and 1951. 
Together with Elizabeth Anscombe and Rush Rhees, von Wright formed the troika of Wittgenstein's literary executors: starting from the early 1950s, he worked intensely to organize, edit and publish Wittgenstein's writings posthumously. With his 1955 “Biographical Sketch", he initiated historical research on Wittgenstein's biography, and his meticulous archival work on Wittgenstein's Nachlass forms the basis of modern historical and philological work on the Wittgenstein papers. Besides that, he also published important early essays on select aspects of Wittgenstein's philosophy. ${ }^{1}$ It is, however, not altogether clear how von Wright was influenced by Wittgenstein in his own systematic work. For von Wright himself, this influence posed a problem, and he often preferred to keep a certain distance from his master and to point out that, in philosophy, he had to "stand on his own feet". Still, he admitted that he had learned from Wittgenstein "more than from any other philosophical author". (von Wright 1999: 137, my translations; compare von Wright 1982: 11.) Indeed, in many respects, Wittgenstein is a figure sine qua non for much of what von Wright did in philosophy from the 1950s on. I believe that no careful reader of The Varieties of Goodness (1963), Explanation and Understanding (1971) or In the Shadow of Descartes (1998) may fail to notice the presence of Wittgenstein in von Wright's work. The problem is how to articulate this somewhat elusive influence and evaluate its significance correctly.

In this article, I discuss Wittgensteinian influences on von Wright's thought from an historical perspective. Through following the development of von Wright's approaches to values and ethics in the decade immediately preceding the publication of his main valuetheoretical treatise, The Varieties of Goodness (= von Wright 1963b, abbr. $V o G$ or Varieties), I identify influences from and reactions to Wittgenstein's later philosophy. My thesis is that ethics and value theory, on which von Wright had done but little systematic work before the early 1950s, offered him fresh philosophical terrain to explore with philosophical tools and methodological ideas he had got from Wittgenstein's later philosophy, especially from his

\footnotetext{
${ }^{1}$ Von Wright 1982 is a collection of von Wright's essays concerning Wittgenstein. The book contains historico-biographical essays on Wittgenstein and his papers as well as articles on select topics of Wittgenstein's philosophy.
} 
Philosophical Investigations (1953, abbr. PI). Von Wright's path to The $V$ arieties of Goodness is followed from 1947, when he re-established his contact with Ludwig Wittgenstein, via two important stations in the early 1950s, up to the emergence of some key ideas formulated in Chapter 1 of The Varieties, which also seem to have significant connections to Wittgenstein's later work.

While this article is not the place to examine the Wittgensteinian aspects of The Varieties of Goodness in detail, it is useful to pinpoint three interlocking levels in which von Wright's approach in that book is, in my view, clearly indebted to Wittgenstein's later philosophy. ${ }^{2}$ (A fourth, less obvious point is added to the list in Section 5.2.) Having these features in mind will also make it easier to see how these influences gradually emerge in von Wright's earlier work.

I. Descriptive and non-reductive approach to conceptual analysis. Von Wright's Varieties provides an account of 'the varieties of goodness' - i.e. the different uses of the word "good" in language. The discussion is highly systematic throughout, but most parts of the book are descriptive in tone: what is sought is an analytical understanding of various factual, rule-governed uses of the word "good". As von Wright argues in Chapter 1 of the book, the varieties of goodness distinguished in the book are not inventions, but familiar phenomena, among which new differences are detected (VoG: 16-17). Furthermore, the author intentionally seems to refrain from attempts at reducing the varieties to one single variety or to some kind of generic goodness: what emerges is, rather, an exposition taking into account both the similarities and differences between the varieties (see esp. VoG: 12-18). It seems to me that this descriptive and anti-reductive approach is much indebted to Wittgenstein's later idea that philosophy should be a descriptive enterprise (cf. PI: \$109, \$124).

II. The use of specific Wittgensteinian concepts and techniques. More particularly, von Wright puts to use several specific concepts or

\footnotetext{
${ }^{2}$ Von Wright's work on values is indebted to Wittgenstein's later thought not so much via content as methodically. I agree in general with Wellman's (1976: 406) proposal that in VoG von Wright "has applied Wittgenstein's philosophical approach to [...] the clarification of the meaning of "good" not merely by "imitating Wittgenstein" but as a "highly original thinker".
} 
conceptual distinctions originating from Wittgenstein. Most importantly, the recurrent reference to criteria of goodness is demonstrably Wittgensteinian in origin (VoG: 4, passim). In discussing technical goodness, von Wright contrasts symptom- and criteria-tests (VoG: 37), building on Wittgenstein's distinction between criteria and symptoms. Furthermore, his discussion concerning the asymmetry of first- and third-person ascriptions of hedonic goodness is, arguably, indebted to Wittgenstein's work on psychological concepts (VoG: $72-73$, see also Hacker 1996: 144), and his occasional uses of simplified scenarios of language use bear some resemblance to Wittgenstein's use of primitive language games as objects of comparison (see e.g. the four different scenarios of instrumental betterness discussed in $V o G$ : 24-29).

III. The aim for a perspicuous overview of ethically relevant concepts. The central task von Wright undertakes in his book is to give a broad overview of concepts that provide the framework for moral evaluation. In fact, one of his main proposals is that moral philosophy should be pursued within a broad conceptual framework consisting of axiological, normative and anthropological concepts ("broad approach to ethics", VoG: 7). It seems that on this level von Wright is indebted to Wittgenstein's ideal of providing a "perspicuous (re)presentation" (Germ. übersichtliche Darstellung) of grammar (PI: \$122).

With these three points in mind, let us now return to the Summer of 1947 and switch to an historical mode of presentation.

\section{Von Wright and the later Wittgenstein: from 1947 to}

\section{2}

\subsection{An Encounter in 1947: "Wittgenstein shakes my soul”}

On 31 July 1947, Georg Henrik von Wright wrote to Ludwig Wittgenstein the following dramatic lines: 
[...] Never before, to my memory, going abroad meant so much to my education.

I learnt an enormous mass [of] philosophy. Why and how it came to be so, you know as well as I do. What will be the consequences of it, is not as yet to be foreseen, - I can only hope they will be of more good than harm, in the long run. I know that a hard struggle is needed before the imported goods will become my own. Certain things will be ejaculated, other things assimilated. If, at the end, no visible traces of your influence remain in my thought, which is extremely unlikely, so shall I at least always have to acknowledge that I learnt from you, how difficult philosophy must be, if it is to be more than a collection of materials for academic controversy and learned conversation. (McGuinness, ed., 2008: 414 = item 370; my italics)

This letter is dated two weeks after von Wright's return from England, where he had spent some two and a half months as a visiting lecturer. During the visit he had given lectures in London, Cambridge and Oxford, and re-established contacts with colleagues and friends. Among those people was Ludwig Wittgenstein, whom von Wright had come to know in early 1939 while working on his doctoral thesis at Cambridge. During the 1947 stay, the two had regular meetings, and von Wright also frequented Wittgenstein's final lecture course concerning the philosophy of psychology. At the point of writing the letter, von Wright had already heard of Wittgenstein's plans of retiring and of his wish to see the young Finn as his successor: but at this point this was talk only, and I doubt whether von Wright took the discussions that seriously. In any case, at the time of writing these lines, von Wright had no idea that he was to spend most of his life working on and publishing Wittgenstein's philosophical Nachlass. ${ }^{3}$

There are some quite astonishing formulations in this letter. After all, at the time of the 1947 encounter, von Wright was no longer the 22-year old doctoral student whom Wittgenstein had learned to know eight years earlier, but a promising 30-year-old full professor of the Swedish-speaking chair of philosophy at the University of Helsinki. He also had a distinct research profile of his own, and his

\footnotetext{
${ }^{3}$ See the description of this trip in von Wright 2001: 124ff., compare also von Wright 1989: 14 and Kruskopf (ed.) 2008: 174-180. For a useful historical overview of von Wright's early relations with Wittgenstein, see Erbacher 2016: 8-13 and 20-25.
} 
doctoral dissertation on the Logical Problem of Induction (1941) had been praised by C. D. Broad in a series of review articles published in Mind (Broad 1944). ${ }^{4}$ Against this background, it is rather surprising to hear that "[ $n]$ ever before, to [his] memory, going abroad had meant so much to [his] education" and that he had "learnt an enormous mass of philosophy". It seems to be implied that this process of learning was massively due to the renewed contact with Wittgenstein. The young Finn seems both puzzled and challenged by this strong influence: "a hard struggle is needed before the imported goods will become my own. Certain things will be ejaculated, other things assimilated." Indeed, it seems that von Wright was fairly sure that the confrontation with Wittgenstein was to leave traces in his philosophy, but was unsure about the nature of these traces: "What will the consequences be", he writes, "is not as yet to be foreseen", hoping that they will, in the long run, be "more good than harm". 5 The 1947 encounter was thus significant for von Wright, and the memory of this significance was to last: more than 50 years later, von Wright named the chapter of his Autobiography describing these meetings "Wittgenstein skakar min själ" "Wittgenstein shakes my soul" (2001: 124, my translation).

It is not altogether easy to see how von Wright himself saw the possible directions of Wittgenstein's influence at the time of writing the letter. Almost certainly he was not thinking about ethics and moral philosophy at the time. In his autobiography he rather states that after his return to Finland he became "obsessed" with his "logical investigations, which lasted two to three years" (2001: 131, my translation). In this period, the seminal "Essay on Modal Logic" (1951a) and the paper "Deontic Logic" (1951b) were written. But these publications were preceded by work on the so-called distributive

\footnotetext{
${ }^{4}$ Published in three subsequent numbers of Mind in 1944 and totalling 67 pages, this must be one of the longest review-articles of a doctoral dissertation ever written.

${ }^{5}$ This formulation implies that von Wright may also have been worried about the strong influence from Wittgenstein. This aspect of the 1947 encounter has recently been discussed by Bernt Österman (2017: 60), who suggests that von Wright was also worried about being able to preserve the integrity of his own thought. For evidence, see von Wright's letter to Göran Schildt on 15 June 1947 (Kruskopf 2008: 173-180), partly translated in Erbacher (2016: 23).
} 
normal forms. ${ }^{6}$ Von Wright often characterized the idea of distributive normal forms as an attempt at generalizing the idea, expressed in Wittgenstein's Tractatus Logico-Philosophicus (= Wittgenstein 1971 [1921]), of logical truths as tautologies by extending the idea from propositional logic to predicate calculus. But this inspiration from Wittgenstein, arguably, comes rather from von Wright's intensive preoccupation with the Tractatus than from the 'shaking' personal encounters in April-July 1947. Even though he had read the Blue Book as early as $1939,{ }^{7}$ and even if this arguably left some traces in his dissertation (1941) and in an early paper "On Probability" (1940), ${ }^{8}$ and despite having seen and read a version of the Investigations in 1947, ${ }^{9}$ in the late 1940s Georg Henrik von Wright was mainly working on logical topics more closely related to Wittgenstein's early philosophy.

\subsection{Two early attempts to outline Wittgenstein's Philosophical Investigations}

In the early 1950s, however, the situation changes. Wittgenstein passed away on 29 April 1951. In his will, he bequeathed to Elizabeth Anscombe, Rush Rhees and Georg Henrik von Wright his vast philosophical Nachlass, authorizing them to publish as many of his "unpublished writings as they think fit" (Kenny 2005: 341). As the three literary executors started collecting the manuscripts scattered around Europe and commenced their editorial work, von Wright familiarized himself better with Wittgenstein's later philosophy and quickly also developed an historical interest in Wittgenstein's biography and literary oeuvre. After returning to Helsinki from his three-and-a-half-year stint as professor in Cambridge for the Spring term 1952, von Wright also ventured to present the main ideas of Wittgenstein's later philosophy to the philosophical public. On 29 October 1952, he gave a presentation on the main ideas of Wittgenstein's then still unpublished Philosophische Untersuchungen in

\footnotetext{
${ }^{6}$ See von Wright 1948 and 1950. This idea was picked up and developed further by von Wright's student Jaakko Hintikka.

${ }^{7}$ Von Wright to Elizabeth Anscombe, 10 March 1952.

${ }^{8}$ The (possible) Wittgensteinian influences in von Wright's early works in the 1940s is a topic in its own right and would deserve a separate treatment.

${ }^{9}$ See von Wright 1989: 14.
} 
front of the Philosophical Society of Finland. ${ }^{10}$ The language of the lecture was Swedish, and 30 people were present in the audience. ${ }^{11}$ In a letter written on 12 November 1952 he informed Elizabeth Anscombe that his lecture had proceeded "roughly according to the following plan":

After some introductory remarks on the origin, scope and literary character of the later manuscripts I first surveyed W's study of language by means of "language-games". The conclusion of this first theme was the family-character of the concepts of language and meaning. Thereupon I talked at some length about the idea of familyresemblances in general and its relevance for the concept of "essence" in philosophy and for the pursuit of conceptual "analysis". The second main theme was W's discussion of what it is to follow a rule. I tried to link it with his criticism of the idea that mathematics needs a foundation and more particularly that logic is the foundation of mathematics. Finally, I took up a related theme from the philosophy of psychological concepts, namely the question "Wie beziehen sich Wörter auf Empfindungen?". I tried, though far from successfully, to draw a parallel between W's criticism of the notion of "foundation" in mathematics and his criticism of the idea that there is a "foundation" of empirical knowledge in states of consciousness. (Von Wright to Elizabeth Anscombe, 12 Nov 1952.)

Judging from this report, the presentation seems to have dealt with the main lines of thought of the first 300 or so remarks of the book. The reception, however, was not particularly encouraging, and was clearly a great disappointment for von Wright. In the same letter to Anscombe he writes:

How far I am myself from understanding these things properly I realized both in the course of writing the paper and by watching the reaction it provoked. The discussions which followed revealed that I had implanted in the most hearers' minds the very misunderstandings I think it is most important to guard against. I was very much discouraged and depressed. Partly because of my inability to do anything better, and partly because of fears concerning the reaction which W's work will

\footnotetext{
${ }^{10}$ This lecture was preceded by another one, given on 24 September 1952, on "Wittgenstein's life and personality and about the Tractatus" (Minutes of the Philosophical Society of Finland and von Wright to Elizabeth Anscombe, 12 November 1952).

${ }^{11}$ Minutes of the Philosophical Society of Finland. The lecture took place some 6 months before the publication of the first edition of the Philosophical Investigations by Blackwell.
} 
provoke even in more enlightened circles than the Philosophical Society of Helsingfors. (Ibid.)

In light of this self-evaluation, von Wright did not get a very encouraging start as an interpreter and exponent of Wittgenstein's later thought. It is regrettable that the manuscript of von Wright's presentation, if it ever existed, seems to have been lost - it would have been a significant document concerning the early reception of the Philosophical Investigations in Finland. The minutes of the meeting are also limited in scope, stating only the topic and language of the lecture, the number of participants, and pointing out that Eino Kaila, Oiva Ketonen, Martti Siirala and Sven Krohn participated in the discussion following the lecture. ${ }^{12}$ It is thus difficult to reconstruct the main arguments of the lecture, apart from the synopsis given in the above letter to Anscombe. Luckily there is at least one testimony concerning the gathering. For Pertti Lindfors concludes his 1992 paper on "Eino Kaila and the Scientific Weltanschaunng" with a passage concerning Kaila's reaction to the main lines of thought of Wittgenstein's Philosophical Investigations, as they were presented by von Wright in the early 50 s at a meeting of the Philosophical Society. ${ }^{13}$ I will quote this passage in its entirety:

Kaila and Hermeneutics. When G. H. von Wright at the beginning of the 50s presented the posthumous work of Wittgenstein to the Philosophical Society of Finland, Eino Kaila welcomed them, to be frank, with hostility; having an appearance and temperament very similar to that of Herbert von Karajan - he was quite simply 'furioso'! The main theoretical argument which Kaila had against Wittgenstein's Philosophische Untersuchungen proposal was that it uses pre-scientific psychological vocabulary, it is hostile to science (the German Natumissenschaft), and it is hostile to experimental psychology. Kaila was irritated by Wittgenstein's view that scientific problems cease to be philosophically interesting when their scientific relevance has been recognized. [V]on Wright said in his lecture that the concept of the kilogram is not philosophically interesting; Kaila replied that on the contrary: the definition of the kilogram belongs to the discussion about measurement in physics, as for example in the discussion about the introduction of [the] CGS system, and is linked with discussion on the

\footnotetext{
${ }^{12}$ Minutes of the Philosophical Society of Finland.

${ }^{13}$ Due to the reference to the topic, time and venue, I am fairly certain that the description concerns the lecture mentioned in the letter to E. Anscombe quoted above.
} 
'scientific' and 'technical' system of measures; hence the definition of the concept kilogram belongs to the philosophically central problem of measurement. (Lindfors 1992: 100) ${ }^{14}$

Unfortunately, this report tells us little about the content of the lecture: the only thing we hear of von Wright having said, allegedly as an example, is "that the concept of the kilogram is not philosophically interesting". As Lindfors was never a great admirer of the later Wittgenstein, whom he vaguely dubs as a representative of 'hermeneutics' above, the report may also be somewhat biased. But it is nevertheless illuminating in the sense that it sheds light on von Wright's strong and even emotional reaction to the poor reception of the talk, which is evident from the letter to Anscombe. The main problem with the talk was perhaps not so much the "unenlightened" audience in general, but the strong reaction it provoked from Eino Kaila, whom von Wright later referred to as his first father-figure in philosophy - the second being Wittgenstein (von Wright 1999: 137). ${ }^{15}$

As I indicated above, no original document of the lecture seems to have been preserved. ${ }^{16}$ The closest document I have found in the archives is among the notes for a lecture course held on Philosophy of Language at the University of Helsinki in the Spring term 1953, i.e. a few months after the lecture concerning the Investigations. This document (= von Wright UP4) is named "Wittgenstein om frågan om språkets väsen" ["Wittgenstein on the question concerning the essence of language"], and it really seems to be a 7-page "Analytical Table of Contents' in Swedish of the first 76 remarks of the Investigations. Comparing these notes with the description of the former lecture's contents given to Anscombe (above), it seems that the first lecture was wider in scope than the presentation given to the students. The shorter presentation was not, however, a great success

\footnotetext{
${ }^{14}$ I am grateful to Bernt Österman for having directed my attention to this eyewitness report.

${ }^{15}$ Eino Kaila had been, since the late 1920s, the most prominent representative of the new logical and analytical movement associated with the Vienna Circle in Finland. Perhaps the unsuspecting lecturer found himself involved in a kind of clash of father-figures, which he had not anticipated.

${ }^{16}$ This is not a categorical statement: it is quite possible that something can still be discovered in the archives. Further testimonies and notes taken by the participants may also be found.
} 
in von Wright's view either: he was disappointed with his presentation and complains to Anscombe:

I tried to explain some parts in the book [i.e. Philosophische Untersuchungen] to my class earlier this year, but found it nearly hopeless. (Von Wright to Elizabeth Anscombe, 7 May 1953.)

Von Wright's two early attempts at presenting the main lines of Wittgenstein's Philosophical Investigations to the Finnish audience thus ended in disappointment.

\section{Von Wright's work on values and ethics in the early $1950 s$}

\subsection{A logical attempt aborted: "On the logic of some axiological and epistemological concepts" (1952)}

Simultaneously with the first attempts at giving an overview of Wittgenstein's later philosophy, von Wright also devoted more attention to questions related to ethics. This interest is partly related to his professional status at the University of Helsinki. After Erik Ahlman's death in 1952 he was, between 1953 and 1959, also taking care of the chair of Social and Moral Philosophy in the Faculty of Social Sciences at the University of Helsinki. In 1952, he published an article titled "On the logic of some axiological and epistemological concepts" in Ajatus. The method used in this paper is analogous to the approach von Wright adopted elsewhere to modal and deontic concepts (see von Wright 1951a and 1951b). His main idea was to explore whether the same logical pattern that characterizes modal and deontic concepts may be applied to various epistemological and axiological concepts such as "valuable" or "certain". The logical pattern von Wright had in mind is that of various kinds of contraries, which may be derived from one basic concept by means of negation. In modal logic, for example, one may take 'possibility' as the basic concept and, by using 'not' as connective, define impossibility as 'it is not possible that p' and necessity as 'it is not possible that not-p'. 
Such conceptual relations may be generalized and formalized by means of what von Wright calls Q-logic. Von Wright's Q-logic operates with a Q-operator (corresponding to a Q-concept), which takes propositions or properties as arguments. As von Wright describes the procedure in his article, the logical analysis starts from a given Q-concept, which is also called a 'middle-concept' in relation to two contraries, which are called the 'first contrary' and 'second contrary'. Semi-formally the approach may be paraphrased as follows:

Let Qp signify the predication of the Q-concept [e.g. 'possibility'] to a Q-subject (proposition or property) p, and let $\sim$ be a symbol for negation that can syntactically occur both before the operator and between the operator and the argument.

From the basic predication Qp [e.g. ' $\mathrm{p}$ is possible'] a first contrary is derived by negating the formula, resulting in $\sim Q p$, [e.g. ' $p$ is not possible, i.e. ' $\mathrm{p}$ is impossible']. The second contrary is derived by negating the formula and the Q-subject, thus $\sim Q \sim p$ [e.g. 'it is not possible that not-p', i.e. 'it is necessary that p']. From the two contraries, a 'proper middle' can be derived as a conjunction of their negations: $\sim \sim \mathrm{Qp} \& \sim \sim \mathrm{Q} \sim \mathrm{p}$ [e.g. 'p is neither necessary nor impossible', i.e. 'p is contingent']. (This is equivalent, via elimination of the double negation, to Qp \& Q p: 'p is possible and not-p is possible'.) The 'proper middle' is thus narrower than the 'middle' term functioning as a basic Q-concept [e.g. what is possible, can also be necessary, whereas no contingent proposition can be necessary].

Together, the Q-concept, the proper middle, and the two contraries make up a family of Q-concepts [e.g. a family of alethic modalities or a family of deontic concepts].

In one part of the paper, von Wright applies the schema of Qlogic and Q-concepts to the expression " $\mathrm{p}$ is valuable". ${ }^{17}$ The application, however, does not seem to be quite straightforward: Whereas, for modal logic, the concept of possibility can straightforwardly be taken as a basic Q-concept, the analogy breaks down in the case of value: A formal requirement of a Q-concept is,

\footnotetext{
${ }^{17}$ Note: 'is valuable' and not goodness in general. From the perspective of von Wright's later thought it is, however, interesting that in 1952 he considers the logic of the words 'of interest', 'useful' and 'needed' as being "the same as the logic of the word 'valuable"' (von Wright 1952: 219). All these concepts are treated in a non-formal manner in The Varieties of Goodness.
} 
von Wright argues, that it should be distributive with regard to disjunction: if Q(p or q), then Qp or Qq. Since 'valuable' does not, in von Wright's view, satisfy this condition, ${ }^{18}$ the basic Q-concept of the logic of value is the somewhat forced "absence of value in the contradictory" i.e. "not-p is not valuable". In this view, " $x$ is valuable" is the second contrary of the basic Q-concept: from "not-p is not valuable" (= middle term) the second contrary is derived via negating the predication and the argument: "not-not-p is not-not valuable", i.e. "p is valuable" (von Wright 1952, 218-219). In this framework, "is valuable" is thus, as the second-contrary of the basic concept, analogous rather to necessity (in modal logic) and universal quantification (in predicate logic) than to possibility or existence. Indeed, unlike in the case of modal logic and logic of quantification, ordinary language does not seem to have anything corresponding to the basic Q-concept of von Wright's 1952 logic of values.

Another complication is mentioned by von Wright later in the paper: according to him, as a formal requirement of Q-logic, the second-contrary of the basic Q-concept should be distributive with regard to conjunction: if $\sim \mathrm{Q} \sim(\mathrm{p}$ and $\mathrm{q})$, then $\sim \mathrm{Q} \sim \mathrm{p}$ and $\sim \mathrm{Q} \sim \mathrm{q}$. In von Wright's value-Q-logic, the second contrary is " $\mathrm{x}$ is valuable". The complication is that the distributivity does not seem to hold in the case of value. Von Wright's counterexample is this: "To have a gun and a cartridge may be of great value to me in a certain situation, but to have only a gun and to have only a cartridge is usually of no value at all" (1952: 225). ${ }^{19}$ In the latter part of the article, von Wright attempts to solve the problem by introducing another operator $\mathrm{C}$ by means of which one may distinguish between qualified and unqualified predications of value. He argues that distributivity with regard to conjunction applies for the unqualified predications of value (von Wright 1952: 224-231). Let us not, however, follow his analysis further. For present purposes it is enough to see that von

\footnotetext{
${ }^{18}$ Von Wright gives no counterexample, but the following scenario comes to mind: It may be valuable that person $A$ or person $B$ is elected as president, but still be valueless that $A$ is elected and valueless that B is elected. Thus, if $\mathrm{V}$ is interpreted as standing for "valuable", $\mathrm{V}(\mathrm{A}$ or $\mathrm{B})$ does not imply $\mathrm{V}(\mathrm{A})$ or $\mathrm{Q}(\mathrm{B})$. The value may, so to speak, reside in the very possibility of there being alternatives.

${ }^{19}$ This criticism is probably related to G. E. Moore's famous idea of organic wholes: in his Principia Ethica he pointed out that that the value of a whole "must not be assumed to be the same as the sum of the values of its parts" (Moore 1966: 28).
} 
Wright tried to apply the logical scheme of the Q-concepts in his analysis of value, and how this approach was beset with certain complications from the start. Von Wright's logical approach to value by means of Q-logic can be summed up in the following table, where analogical treatments of modal and quantificational concepts are also illustrated:

\begin{tabular}{|c|c|c|c|c|}
\hline Q-family: & Possibility & Quantification & $\begin{array}{l}\text { Value (cf. p. } \\
\text { 219) }\end{array}$ & $\begin{array}{l}\text { Value, } \\
\text { formally }\end{array}$ \\
\hline $\begin{array}{l}\text { Middle: = } \\
\text { Q-concept }\end{array}$ & $\mathrm{Qp}=$ 'p is possible' & $\begin{array}{l}\mathrm{Qp}=\text { 'something } \\
\text { is } \mathrm{p}^{\prime}\end{array}$ & $\begin{array}{l}Q p=\text { 'not-p is not } \\
\text { valuable' = 'not } p \\
\text { is valueless' }\end{array}$ & $\sim V \sim p$ \\
\hline $\begin{array}{l}1^{\text {st }} \\
\text { contrary: }\end{array}$ & $\begin{array}{l}\sim Q p=\text { 'p is not } \\
\text { possible', i.e. 'p is } \\
\text { impossible' }\end{array}$ & $\begin{array}{l}\sim Q p=\text { 'nothing is } \\
p^{\prime}\end{array}$ & $\begin{array}{l}\sim Q p=\text { 'not- } p \text { is } \\
\text { not valueless' } \\
=\text { 'not-p is } \\
\text { valuable' }\end{array}$ & $\sim \sim \mathrm{V} \sim \mathrm{p}=\mathrm{V} \sim \mathrm{p}$ \\
\hline $\begin{array}{l}2^{\text {nd }} \\
\text { contrary: }\end{array}$ & $\begin{array}{l}\sim Q \sim p=\text { 'not } p \text { is } \\
\text { not possible', i.e. 'p } \\
\text { is necessary' }\end{array}$ & $\begin{array}{l}\sim Q \sim p= \\
\text { 'everything is } p^{\prime}\end{array}$ & $\begin{array}{l}\sim Q \sim p=\text { 'not not- } \\
p \text { is not not } \\
\text { valuable' = 'p is } \\
\text { valuable' }\end{array}$ & $\sim \sim \mathrm{V} \sim \sim \mathrm{p}=\mathrm{Vp}$ \\
\hline $\begin{array}{l}\text { Proper } \\
\text { middle: }\end{array}$ & $\begin{array}{l}\mathrm{Qp} \& \mathrm{Q} \sim \mathrm{p}=\text { 'p is } \\
\text { possible and non-p } \\
\text { is possible', i.e. 'p is } \\
\text { contingent' }\end{array}$ & $\begin{array}{l}\text { Qp \& Q p = } \\
\text { 'something but } \\
\text { not everything is } \\
\text { p' }\end{array}$ & $\begin{array}{l}\text { Qp \& Q p } \\
\text { 'neither p nor } \\
\text { non-p is valuable', } \\
\text { 'p is value- } \\
\text { indifferent', 'p is } \\
\text { value-neutral'. }\end{array}$ & $\sim V \sim p \& \sim V p$ \\
\hline
\end{tabular}

Table 1. Q-logic (von Wright 1952) illustrated.

In retrospect, von Wright considered this "first attempt at formal logic of axiological concepts" plainly "worthless" (2001: 204, my translation). The main problem with the approach, he explained in his 1989 Intellectual Autobiography, was that the general logical pattern characterizing the value concepts is different from those which characterize the different families of modal concepts. He added that these differences especially concern the nature of contrariety of the axiological opposites such as 'the good' and 'the evil', and that the 'middle term' between the contraries (i.e. 'value-neutral') is of a 
"different logical nature from the 'middle' between the modal opposites" (von Wright 1989: 31). ${ }^{20}$

With hindsight one may, I think, also argue that the 1952 approach was, if not plainly worthless, at least somewhat forced. As pointed out above, von Wright had to accept the concept "not-p is not valuable", as the basic Q-concept instead of 'p is valuable'. But unlike for similar basic Q-concepts of predicate, modal and deontic logic, there seems to be nothing corresponding to this basic middleconcept in ordinary language. This sort of worry, however, already implies a change of philosophical perspective. It seems that in 1952 von Wright was looking for logical structures underneath the surface of ordinary language and deemed ordinary language as a rather unreliable guide for understanding the more fundamental conceptual patterns underlying it. Indeed, he openly admitted that it "frequently happens that there is no name for one or for several" of the notions constituting a family of Q-concepts. He also complained that the lack of certain expressions in ordinary language may often "obscure our insight into the logic of quite a number of philosophically interesting notions" (von Wright 1952: 217-218). I thus suppose that von Wright would not, in 1952, have been convinced by this sort of criticism. But since this appears to be a major point where he seems to have changed his mind around 1953, his later non-formal approaches to axiological concepts may be fruitfully viewed against the background of his earlier attempt at a Q-logic of values.

\subsection{A Wittgenstein-inspired approach to value judgments: "Om moraliska föreställningars sanning" (1954)}

We have so far witnessed two distinct but temporally parallel developments in von Wright's intellectual interests at the turn of the 1950s: a growing preoccupation with Wittgenstein's later work and a sequel of attempts at applying logical tools to new conceptual areas. But we have also encountered two disappointments: a failure of applying the logical schema of Q-concepts to the concept of value,

\footnotetext{
${ }^{20}$ In his Intellectual Autobiography von Wright does, however, note that he used to return to this logical topic "from time to time in the following years" and used to "think about it when attending boring committee meetings" (1989: 31). Another kind of logical approach to values is undertaken in The Logic of Preference (von Wright 1963a). The relation of the approach probed in this book to the Varieties is unclear and merits further research.
} 
and two attempts at presenting Wittgenstein's upcoming Philosophical Investigations to the public in Finland on the other. Around 1953-4, however, these two distinct interests meet as von Wright abandons formal approaches to values in favour of a Wittgenstein-inspired analysis of (moral) value judgments. With regard to the later Wittgenstein, he thus switches from the mode of presentation to the mode of application. Let us now see how he did this.

In 1954 von Wright published an article written in Swedish called "Om moraliska föreställningars sanning" ["On the Truth of Moral Conceptions"]. ${ }^{21}$ The article examines the ethical theories of Edward Westermarck and Axel Hägerström critically - but also discusses more modern emotivist ethical theories associated with names such as Charles Stevenson or Ingemar Hedenius - and finishes with an original 'Wittgensteinian' analysis of moral value judgments. In fact, von Wright's critical remarks seem implicitly directed at his contemporaries rather than at Westermarck and Hägerström, for at the very beginning of the article he states that the time seems ripe for "a critical revision of emotive theories in ethics [Swe. känsloteorierna i etiken] and in theory of values in general" (von Wright 1954: 48). He then proceeds to mention formal logic as one possible approach in this revision (without, however, mentioning his 1952 attempt), but then moves quickly to what he calls modern analysis of meaning or philosophical semantics. ${ }^{22}$ As he writes in the paper, recent developments have proven that the philosophical analysis of meaning has "asserted itself as a fruitful method also in clarifying the subtle structures of meaning of ethical and aesthetic concepts", which in turn has "sharpened our eyes for conceptual nuances, to

\footnotetext{
${ }^{21}$ The article is based on a lecture von Wright gave in 1953. The article's name is an allusion to Axel Hägerström's paper with the same title from 1911. Von Wright's article has not been translated into English, and I provide here a translation of selected passages from the article, with key expressions given in the original language in square brackets. Mikko Salmela (2003) is one of the few who have devoted attention to this article.

${ }^{22}$ What is it that von Wright means by philosophical semantics? - It seems that he does not so much have in mind the 'philosophical semantics' of Tarski or Carnap, but rather the 'semantic philosophers' who proceed by analysing meanings of words used in language. This distinction is made clear in Logik, filosofi och språk (1957b, chapter "Filosofisk semantik"). It is also probable that in his 1954 use von Wright was influenced by two publications discussed in his 1953-1954 seminar exercises that both make heavy use of the idea of 'semantics': Susanne Langer's (1941) and Bernard Heyl's (1943). This would explain the reference to the approach's fruitfulness in aesthetical analysis.
} 
which emotivism in the theory of values has not been able to do justice" (ibid.: 49).

According to von Wright's diagnosis, the emotivist theories in ethics have been based on two main motivations or presuppositions that are both mistaken.

(i) The first source of motivation consists of certain "views concerning the concept of the meaningful sentence". According to these views, all meaningful sentences can be divided into two (and only two) groups: the logico-mathematical sentences on the one hand, and empirical sentences on the other. Since value judgments belong to neither of these groups, they lack empirical content and are thus meaningless. (ibid:: 54)

(ii) The second source of motivation consists in attempts to reduce the meaning of value judgments to such linguistic components that cannot be true or false. As an example, von Wright mentions the attempt to analyse value judgments of the form "this is good" into imperative statements of the form "Do this!" - which, of course, are trivially not true. (ibid:: 54-55)

Von Wright finds severe faults in both presuppositions. The first suffers from what von Wright calls "the dogmatism of presupposed meanings" [Swe. forutfattade meningars dogmatism]. By this dogmatism von Wright means an attempt to define the set of meaningful sentences by certain criteria in advance, which he deems misguided. Here a direct reference is made to Wittgenstein - and quite explicitly to the late Wittgenstein: "It seems to me that it was one of Wittgenstein's greatest contributions to have, in his later thought, so convincingly shown how futile any attempt of drawing boundaries around the concept of meaningfulness is bound to be" (ibid.: 55).

The second presupposition is, on the other hand, guilty of a reductive fallacy or mistake [Swe. reduktionistiska felet]. A reductive fallacy is committed when two things that are logically or conceptually related, are, on the basis of this relation, identified with one another or one of them is reduced to the other: say, value judgments to expressions of emotions or to imperative statements (ibid.). While talking about the reductive fallacy, von Wright does not mention Wittgenstein. But I find it hard not to detect a certain kinship with Wittgenstein: 
the point is that instead of plain discussion of factual grammatical similarities and differences between some concepts (or language games), a reduction or identification is undertaken (compare, e.g. PI: $\$ 124$, \§130-131).

Von Wright's criticism of emotive theories in ethics is thus partly based on insights from the later Wittgenstein. But Wittgenstein surfaces again later in the article when von Wright turns to his own analysis concerning the possibility and nature of truth in moral judgments. He even states that for his method he feels "indebted to Wittgenstein", adding that "[ $t]$ his great figure of contemporary intellectual life has not himself systematically treated the problematics concerning value" (von Wright 1954: 58). Von Wright starts by addressing the question of meaningfulness of value judgments ((i) above). His solution is to bypass the whole problem:

The question of whether value-sentences are meaningful I shall brush aside. The plain fact that such sentences are used and that they play an important role in communication by means of language, is for, our purposes, a 'proof' of their meaningfulness.

My intention is to investigate how value-sentences and words are used in language. Here we are primarily interested in the everyday uses [Swe. användningen $i$ vardagsspraket]. We are not concerned with making some new inventions, and even less with giving some regulations concerning the uses, but merely with reminding us of certain facts that are open to view [Swe. $i$ öppen dag liggande fakta]. The benefit of such a reminder can perhaps be described as a rescue from one-sidedness of the philosophical perspective concerning the truth of moral issues.

A certain aphorism in Wittgenstein goes like this: 'Du musst Neues sagen und doch lauter Altes. Du musst allerdings nur Altes sagen - aber doch etwas Neues.' (von Wright 1954: 58-59)

As should be evident from the passage, von Wright here makes heavy use of methodical ideals, maxims and conceptual tools taken from Wittgenstein's Investigations. It contains an explicit reference, given in a footnote, to PI $\$ 127$ ('assembling reminders') but alludes to several other methodical remarks in the PI, at least to PI $₫ 43$ ('meaning and use'), PI $\$ 116$ ('everyday uses'), $\$ 124$ ('only describe'), $\$ 126$ ('everything is open to view') and \$129-130 ('no regularisation'), and perhaps also to PI $\$ 593$ ('one-sided diet as a 
cause of philosophical sicknesses'). Besides, the directly quoted "aphorism" stems from MS 124: 28 (dated 11 June 1941) and is now published in Vermischte Bemerkungen (Wittgenstein 1994: 84). ${ }^{23}$ Furthermore, a contrast to von Wright's 1952 logical approach is evident: while he, in his 1952 essay, tended to view logical patterns as something primary to ordinary language, he now emphasizes the philosophical importance of the very ordinary uses and of "facts that are open to view".

After these methodical remarks, von Wright introduces, in reference to Wittgenstein, the concept of language games, and introduces a language game played with the expressions "vara" and "anses vara" or "hålles för" - which translate into English somewhat badly as "is" and "is held to be". The next step in the argument is to introduce a distinction between symptoms and criteria:

We may call the grounds on which something is held to be $x$ the symptoms of $\mathrm{x}$, and the grounds on which something is declared really to be $x$ the criteria of $\mathrm{x}$. The form of a whale's body and some of a whale's life-habits are 'fish-symptoms', but none of the symptoms constitute a 'fishcriterion'. (ibid:: 59)

The passage does not contain a reference to Wittgenstein. But since the distinction is introduced by contrasting symptoms and criteria, which is seldom done explicitly in the Investigations, the most probable source is the Blue Book. (Wittgenstein 1972: 24-25), which von Wright had studied already in 1939. ${ }^{24}$ Having introduced this distinction, von Wright presents a series of examples of different language games', to which the distinction between 'is' and 'is held to be' applies in different ways. At one end of the spectrum, 'is' and 'is held to be' form a fairly sharp contrast: e.g. in establishing whether a whale is a mammal, we may refer to commonly accepted zoological classificatory criteria, even though whales share many 'symptomatic features' with fish. At the other end of the spectrum, 'is' and 'is held to be' are more or less conflated, or, at any rate, the distinction between them is blurred. Von Wright's example of the latter case is

\footnotetext{
${ }^{23}$ Later in the article, von Wright also refers to the problem of evaluating the length of the 1-metre bar in Paris (von Wright 1954, 66). Though no reference is given, this is undoubtedly an allusion to Wittgenstein's PI: $\$ 50$.

${ }^{24}$ Von Wright to Elizabeth Anscombe, 10 March 1952.
} 
'prosperity'. The criteria of establishing whether N.N. is prosperous are somewhat open and relative, and the distinction between symptomatic features and criterial features of prosperity is blurred: one may refer to the balance of N.N.'s bank account, to his lifestyle, to his possessions, etc. In evaluating an individual problematic case, one may have to decide which 'symptomatic features' of prosperity are stressed (von Wright 1954: 59-61). ${ }^{25}$

After these preliminary observations, von Wright moves on to discuss language games of moral judgments: do they, typically, allow for a distinction between "is" and "is held to be", i.e. whether there are criteria in contrast to symptoms associated with moral judgments?

Somebody says: 'I think that act was good'. Another asks: 'Why?'. Usually we are in a position to answer such a question. Let us now see what kind of answers are given.

We can straight away say that an answer that is usually not given is: 'Because I want to use the word "good" in this way' or "Because the act arouses in me an emotion of acceptance'. Such reaction we should, in normal cases, not consider as a 'answer' to the question, but rather as a refusal to answer. (ibid:: 63)

Von Wright's point is this: an emotivist account does not do justice to how moral discourse operates in ordinary situations and how grounds for moral evaluations are given. There are, however, in von Wright's view, also several types of proper answers to the question. In the text of the article von Wright mentions subsuming the act under a virtue (such as courage or helpfulness) as one possible proper answer, and in the important footnote 55 two further possibilities are mentioned: a reference to utilitarian or hedonic qualities related to the consequences of the act. Such grounds or reasons given to the question concerning an act's moral worth are, in von Wright's view, often given by means of concepts that are "considerably more 'stable' than those of good and bad" (ibid:: 63). ${ }^{26}$ And since this kind of reference to criteria of moral goodness is often possible, the

\footnotetext{
${ }^{25}$ For the purpose of this article, I have somewhat simplified von Wright's argument.

${ }^{26}$ This passage seems to anticipate the distinction between "thick" and "thin" concepts of evaluation, familiar from Bernard Williams (2006 [1985]), but stressed in various ways already by Elizabeth Anscombe (1958) and Philippa Foot (1958).
} 
distinction between "is" and "seems to be" has a footing in the realm of moral discourse.

Thus, von Wright aims at establishing that, in ordinary discourse, moral judgments are, pace the emotivists' claims, often true or false in the sense that such judgments are backed up by grounds or reasons, which refer to criteria of (moral) goodness. Moral judgments are thus true in relation to a framework of asking and giving reasons. This, however, does not apply to all cases. There are also situations that are not clear-cut and where a discussion concerning the proper criteria of ethical evaluation may be raised. What kinds of reasons can be given for choosing one framework of evaluation (set of criteria)?

The next step in the article is, indeed, to pose the question in what way there may be dispute about the criteria of moral judgments, and how such disputes are set. Here von Wright's answer, however, does not seem to be clear cut. On the one hand, he tends to compare such choices with definitions, claiming that they precede the question of truth: in this sense such choices are stipulative in nature. But on the other, he also argues that there can be argumentation concerning ethical principles (criteria of moral judgments). In his view, such argumentation typically takes place in logical surroundings where several possible 'symptoms' of moral goodness compete for the position of the final criterion: in addition to virtues, consequences of actions and intentions behind the acts also have moral relevance. In this sense the choice among the 'competing' criteria is not arbitrary or subjective. Again, we can spot certain rhetorical moves familiar from Wittgenstein's Investigations in the argument:

Against those who claim that one cannot give 'reasons' for a value judgment that declares a value standard, and that such declarations are therefore purely 'subjective and arbitrary', we have the right to counter: this is not the way the words 'reason', 'subjective' and 'arbitrary' are used - except perhaps when we are doing philosophy. And I have tried to show that the reason why we can talk about reasons in the choosing of moral criteria is to be found in the factual use we make of different kinds of circumstances in classifying actions as good, indifferent or bad. (Ibid.: 67) 
This answer does not really solve the puzzle of choice of criteria. It mainly points out that the search for such criteria takes place in surroundings where several natural and possible candidates are present. But von Wright does not offer any, as it were, 'transcendent' criterion by which to make the final selection. It seems to me that his final answer is that such a choice precedes the question of truth and has more affinities with a definition than with any kind of measuring.

To sum up: We have seen that von Wright makes use of the later Wittgenstein both in the critical and constructive parts of the 1954 article. The gist of von Wright's positive argument is that the examination of value judgments is tightly connected with the investigation of our practices of giving reasons for value judgments. He motivates his descriptive approach by reference to Wittgenstein's 'method' (p. 58) and he puts to constructive use many distinctions and techniques stemming from Wittgenstein's later philosophy (meaning and use p.58, criteria/symptoms p. 59; language game p. 59; use of fictional examples in comparisons p. $59 \mathrm{ff}$.). He also refers to, both explicitly (quotation on p. 59; reference to PI: $\$ 127$ on p. 58) and implicitly (the example of the 'Urmeter' of PI $\$ 50$ on p. 66), to Wittgenstein's later works. In many passages one can also detect certain stylistic imitations of select passages in the Investigations: for example, on p. 67 the ironic "when we are doing philosophy" [Swe. "när man filosoferar') is a common Wittgensteinian topos (see e.g. PI: $\$ 11, \$ 38, \$ 194, \$ 592$ and \589), and "the rescue from one-sidedness" [Swe. rättelse av ensidighet] on p. 59 may be an allusion to PI: \593. It seems to me that later (or earlier) von Wright never comes this close, either stylistically or methodically, to the Wittgenstein of the Investigations.

One may, however, speculate a bit why Wittgenstein plays such a major role in this article. One motivation is surely, that ethics simply was for von Wright in the 1950s, a novel philosophical terrain where he could experiment with some ideas stemming from Wittgenstein's later work. But there is also another side to the issue: as is evident from the letters to Elizabeth Anscombe, quoted above on p. 8 and 11, von Wright had worries about the reactions and misunderstandings Wittgenstein's Investigations would provoke from 
the philosophical community. Given von Wright's own frustrations with giving direct presentations concerning the Investigations, and his will to promote Wittgenstein, it seems to me likely that von Wright's 'value-theoretical' experiments with Wittgensteinian tools were also meant to demonstrate the fruitfulness of Wittgenstein's later work.

Von Wright remarked later that reading this long-forgotten article may still be useful to some extent (2001: 204). It would be interesting to have a look at how his critical remarks on emotivism relate to other contemporary or later criticism. ${ }^{27}$ But more than anything this article helps us understand better some basic starting points of von Wright's approach in the Varieties of Goodness. At least we learn that the criterial approach of goodness, which plays such a central role in the $V$ arieties, developed out of a critical encounter with the emotivist theories in ethics. I should also like to claim that in the $V$ arieties, von Wright would still accept his earlier criticisms of the 'dogmatism of presupposed meanings' and of the 'reductive fallacy', spelled out in the 1954 article. This is evident, I believe, from his reluctance to reduce any of the 'varieties of goodness' to any single basic meaning of "good". (Compare points I and II on p. 3-4 above.)

\section{Lecturing on moral philosophy in the mid 1950s: further ideas in statu nascendi}

As far as I know, between the 1954 article and The V arieties of Goodness von Wright did not publish anything directly related to moral philosophy. But as already pointed out above, he was the acting professor of Social and Moral Philosophy from 1953 until 1959. In those years we find him lecturing on many topics related to ethics and philosophy of values at the University of Helsinki. ${ }^{28}$ Some

\footnotetext{
${ }^{27}$ The article seems to precede some distinctions that surface again in Urmson's The Emotive Theory of Ethics (1968) by more than a decade. An interesting case is what Urmson calls the distinction between "standard-using" and "standard-setting" uses of "good". A similar distinction appears in von Wright's paper. Interestingly, Urmson (1968: 66-71) introduces the distinction as a correction to Stevenson's emotive theory of ethics, which is also discussed by von Wright in the paper. See also n.26 above.

${ }^{28}$ The topics and schedule of von Wright's lectures and seminars in the 1950s may be reconstructed fairly accurately on the basis of the annual volumes of Helsingin yliopiston
} 
relevant lecture manuscripts from this period have been preserved in the archives. Of these manuscripts, the most substantial is a roughly 100-page, (mostly) typed manuscript (mostly) in Finnish called "Luonnokset käyt. fil. luentoihin Helsingin yliopistossa 19531959" (or 1957?) [Sketches for lectures in Pract. Philosophy at the University of Helsinki 1953-1959 (or 1957?)] (= von Wright UP2).

The last section of the manuscript, running from page 47 to 88 concerns values and goodness. This section is introduced by four typed pages of jottings (exceptionally) in English, which, to my mind, seem to include a whole "Gedankengang" leading to the idea, pivotal in The Varieties of Goodness, that the uses of "good" come in varieties and that the interrelations of the varieties seem to elude successful analysis in terms of traditional classificatory devices (see the systematic discussion in $V o G, 12-19)$. The passage as a whole testifies to von Wright's emerging descriptive account of the varieties of goodness, with growing sensitivity to conceptual differences and similarities between them. ${ }^{29}$ The passage runs as follows:

Ambiguity of words and vagueness of concepts. Is "good" ambiguous and good vague?

Vagueness and family resemblance. Examples.

The notion of generic meaning. Examples: Logical, physical, human possibility. Indicative, imperative, etc. sentence. Scarlet red, light red, dark red. Is there a generic good? Does "good" in "a good man" and "a good wine" mean the same? Is "goodness" common to moral and hedonic goodness?

If there is not a generic good, the word seems to be ambiguous. There are various kinds of goodness, either utterly distinct or analogically related. All alternatives seem implausible.

The distinction between attributive and predicative adjectives. "Great" and "small" as examples. / A good parallel to "good" and "bad". Note "great"-"big" and "bad"-"evil"./ "Strong" and "weak".

\footnotetext{
objelma, von Wright's personal notebook (von Wright UP1), and his biographical writings (von Wright 1989 and 2001).

${ }^{29}$ Indeed, two pages earlier in the lecture manuscript, von Wright warns his listeners - in a characteristically Wittgensteinian tone - of the forceful "grammatical analogies" that must not "be allowed to mislead us" (von Wright UP2, p. 46a) Cf. PI \$140 and \$304.
} 
The idea that good and bad are always attributive. "Good" would then mean "good of its kind".

It would seem that this is a very important aspect of goodness, but that it is not all-exhaustive. Consider "good-tasting", "good-smelling", "good-looking". The "I like it" use of "good". Consider also the "good for" use of "good". The "I need it" use of good.

The purpose of food is to nourish, to answer the needs of the human body. "Good food" is food which is good for its purpose. But "good" can also mean "good-tasting". And the purpose of some food is to please the taste.

"I like it", "I need it", "I want it". Hedonic, instrumental and terminal goodness.

"This man is morally good". His morals, moral character is good. Is moral goodness attributive of "man"?

Good and praise. Good and commending. Is there is [sic] descriptive use of "good"?

It would seem that one can never raise the question of whether a thing is good without meaning either "good of its kind" or "good for its purpose" or "pleasant" or "needed" or "wanted". (von Wright UP2, p. 48a)

The final paragraph is crucial: the point is that goodness appears in conceptual varieties, and there is no such thing as general or common goodness. In every case, one has to determine what sort of goodness one is talking about. Another pivotal idea of the $V$ arieties which also seems to be formulated for the first time in these lecture notes is the proposal of a broad approach to ethics: the suggestion that specifically moral notions should be invested in the more comprehensive framework of axiological, normative and anthropological concepts (compare $V o G: 7) .{ }^{30}$ In the notes, von Wright warns of the tendency to confine the discussion in ethics to the 'narrow' concepts of moral goodness or moral ought:

In what follows we shall talk of one value only, goodness and its contrary, badness // evil.

We shall talk about goodness in the broadest possible sense.

\footnotetext{
${ }^{30}$ Compare also von Wright's criticism of the conceptual autonomy of morals and of the Kantian tradition in $V o G, 1-2$.
} 
Goodness in general is a much wider concept than moral goodness. The contrary of general good is bad. The contrary of moral goodness is evil.

Ethics has suffered from a tendency to focus exclusively on moral goodness and moral ought. (von Wright UP2, p. 47, my translation from Finnish. ${ }^{31}$ )

Even though written mainly as rough notes for lectures for fairly elementary students, this course seems to cover roughly the main topics of both Norm and Action (von Wright 1963c) and The Varieties of Goodness (von Wright 1963b). Though the notes are surely preliminary and lack the sophistication of the published books, they may, in my view, be considered the earliest 'preliminary' version of the thoughts that eventually led to the two series of von Wright's Gifford Lectures in 1959-1960. At least they show some of the key ideas of the later books in statu nascendi. And perhaps it is justifiable to add that these notes also put von Wright's own descriptions concerning the genesis of The Varieties in a new light. In his autobiographical writings he often gave the impression that he started, more or less, his work on the Varieties "from scratch" in the summer of 1959, producing the first MS of the lectures in a few months (see 1989: 34 and especially 2001: 202). But since these lectures seem to be earlier than this, it seems that many key ideas of the book had already been born earlier. ${ }^{32}$ It is a pity that it seems difficult to give an exact date to these lectures. ${ }^{33}$

\footnotetext{
${ }^{31}$ Since this is an unpublished item, I give the original text in toto: "Seuraavassa puhumme vain yhdestä arvosta, hyvästä ja sen konträäriarvosta, huonosta / pahasta. // Puhumme hyvästä mahdollisimman laajassa merkityksessä. // Hyvä yleisessä mielessä on paljon laajempi käsite kuin moraalinen hyvä. Yleisen hyvän konträäri on huono. Moraalisen hyvän konträäri on paha. // Etiikka on kärsinyt siitä, että siinä on usein tahdottu keskustella vain mor. hyvästä ja mor. pitämisestä.”

${ }^{32}$ It is true that von Wright sometimes notes that he should like to see Norm and Action (1963c) and The Varieties of Goodness (1963b) as fruits of his long preoccupation with the questions of Social and Moral Philosophy, and that he "should like to think of the book [i.e. $V o G]$ as the fruit of reading and thinking which had engaged me for a much longer period" (1989: 34). If what I claim above is correct, this earlier engagement had also given birth to many central theses of the book.

${ }^{33}$ The indication "1953-1959 (1957?)" written on the archive file only gives a rough guideline for dating the notes, in fact only indicating the years between which von Wright was responsible for the Finnish lectures on Social and Moral Philosophy. Furthermore, the last digit is 1957 on some documents, 1959 on others. From the pagination it is evident that the lectures have been revised many times, the present version probably corresponding to
} 


\section{Broadening the scope: Approaching The Varieties of Goodness}

\subsection{An 'Übersichtliche Darstellung' of ethically relevant concepts?}

Why have I mentioned these lectures and pointed out how some central ideas of The V arieties of Goodness first seem to be expressed in them? The reason is that the lecture typescript seems to provide us a kind of 'missing link' between the 1954 Wittgensteinian article and the 1963 book. It seems that the teaching responsibilities von Wright had as temporary holder of the chair of Social and Moral Philosophy in Helsinki provided him with a kind of test-laboratory where his thinking on ethics evolved in the mid 1950s. Perhaps these lectures also encouraged him to give a broad overview of both the normative and axiological branches of moral philosophy - thus extending his earlier rather narrow approach.

In my view, by far the biggest difference between the 1954 " $\mathrm{Om}$ moraliska föreställningars sanning" and the 1963 The Varieties of Goodness is the difference in scope: unlike the 1954 paper, The $V$ arieties is not confined to the criterial analysis of value judgments but rather aims at a broad conceptual overview of the whole phenomenon von Wright calls 'the varieties of goodness'. Some concepts derived from Wittgenstein that played a central role in 1954 are still in use, though they are now never introduced in relation to Wittgenstein: the frequent discussion of criteria, and the descriptive and non-reductive tone remain. But some other concepts, such as the use of language-games as objects of comparison, are hardly explicitly used. ${ }^{34}$ Furthermore, the book contains only one reference

the course given in the late 1950s. From the fact that the lecture typescript (quoted above) contains an implicit reference to Peter Geach's distinction between predicative and attributive adjectives introduced in his "Good and Evil" (1956), a terminus post quem may be derived for the pages typed in English. This, however, is not December 1956 (The publication of Analysis 17: issue 2) but summer 1956, for Geach had sent von Wright a copy of his article already in July 1956 (Peter Geach's letter to von Wright, 26 July 1956).

${ }^{34}$ See, however, e.g., the four different scenarios of instrumental betterness discussed in VoG: 24-29. The scenarios may, perhaps, be taken as four 'language games' played with expression "better knife". Here the possible connection with Wittgenstein is not explicit, however. If originally indebted to Wittgenstein, uses of simplified 'language games' now seems firmly integrated into von Wright's systematic work. 
to the later Wittgenstein, critical in tone. ${ }^{35}$ Nor does von Wright state that his method derives from Wittgenstein. Even less does the book contain clear stylistic imitations or allusions to Wittgenstein.

I suggested above that the Wittgensteinian approach of the 1954 paper may be partly related to von Wright's will to promote the later Wittgenstein by applying his insights rather than by describing his ideas. In the late 1950s, however, it was already quite obvious that Philosophical Investigations had been a success, and was well on its way to becoming a modern philosophical classic. Thus, this motivation of promoting Wittgenstein by imitation and application withers. The influences that remain are thus subtler and often implicit rather than explicit - and the stylistic allusions disappear almost completely. This meant that von Wright could, even though originally (in 1954) much indebted to Wittgenstein's methodical ideas, distance his own systematic work from these influences.

In Section 1 (p.3-4 above), I referred to and characterized three interlocking levels of late Wittgensteinian influences in the $V o G$ : I. A descriptive and non-reductive approach to conceptual analysis, II. The use of specific Wittgensteinian concepts and techniques, and III. The aim for a perspicuous overview of ethically relevant concepts. Above, we have already seen how von Wright came to prefer a mainly descriptive approach in his value theoretical work, and how he integrated into his thought various systematic tools from the later Wittgenstein. Von Wright's broadening scope of investigation, which is evident from the lecture typescript, may well be viewed in relation to point (III).

This claim, however, calls for some comment. I have not found direct evidence for the thesis that von Wright's proposal of a 'broad approach to ethics' ( $V_{0} G$ : $6-8$ ), would be motivated in relation to Wittgenstein's notion of "perspicuous (re)presentation" (Germ. übersichtliche Darstellung), the centrality of which is spelled out in PI: $\$ 122 .{ }^{36}$ The issue is also complicated by the ideal itself being open to

\footnotetext{
${ }^{35}$ Von Wright criticizes the Wittgensteinian idea that the interrelations between the varieties of goodness might be explained by family resemblance ( $V o G: 15-17$.) The reference is probably to PI \$77, though no exact reference is given. For more details, see Klagge (2019) and my critical reply to his analysis (Jakola 2020).

${ }^{36}$ PI \$122.2 runs as follows: "Der Begriff der übersichtlichen Darstellung ist für uns von grundlegender Bedeutung. Er bezeichnet unsere Darstellungsform, die Art, wie wir die Dinge sehen. (Ist dies eine "Weltanschauung'?)"
} 
radically different interpretations. ${ }^{37}$ There is, however, some indirect evidence for this kind of influence.

First, von Wright's unpublished first Gifford lecture "Approaches to Moral Philosophy" from 1960 contains indications that he tended to articulate his broad approach to ethics as being indebted to stimuli stemming from Wittgenstein's later work. He writes:

$[1 \mathrm{t}$ is interesting to note that in very recent times something which might be called an Anglo-Saxon analogy to German philosophical Anthropology seems to have begun to germinate. Here too the influence of Wittgenstein is felt. What I am thinking of is a new interest in concepts which, although themselves non-ethical, are central to the correct account of ethically relevant situations or of moral phenomena. (von Wright UP3, I-v-15b ${ }^{38}$ )

The passage occurs in a context where von Wright discusses the idea of philosophical anthropology or research into psychological concepts that refer to man as a whole - an approach he viewed as one possible way of pursuing ethics in a broad sense. ${ }^{39}$ It is not altogether clear what kind of Wittgensteinian influences von Wright had in mind and how he would have related his own approach to them. Von Wright's open-ended list of examples of ethically relevant concepts includes those of act, activity, intention, will, motive, reason, needs, wants, character and pleasure (ibid.). From these examples one may surmise that von Wright was mainly thinking of Wittgenstein's later work on psychological concepts rather than his

\footnotetext{
${ }^{37}$ The central questions are whether "Darstellung" should be translated as "representation" or "presentation", and what exactly is being presented / represented. The standard interpretation is that of Baker and Hacker, who argue that what Wittgenstein strived for was a surveyable representation of the grammar of our language, see Baker and Hacker (2005: 307-334). This interpretation, which is also reflected in Hacker's and Schulte's 2009 translation of the remark, has been challenged by many, including Gordon Baker in his later work, see Baker (2004: 22-52).

${ }^{38}$ I have given a normalized transcription of the passage, which incorporates von Wright's many hand-written deletions and additions to the original typed version.

${ }^{39}$ The three alternatives mentioned in the lectures are philosophical anthropology, general theory of value, and general theory of goodness, the latter one being the approach adopted by von Wright. Regarding the anthropological approach, an indirect reference is made to Elizabeth Anscombe's “Modern Moral Philosophy" (1958), which von Wright seemed to view as the main proponent of the 'anthropological' version of the broad approach to ethics. Compare VoG: 7-8, where a similar allusion to Anscombe's work occurs.
} 
methodical suggestions. Consequently, he may not primarily have had his own goodness-oriented approach in mind. But the issue is complicated by the fact that the final sentence of the passage, emphasizing the importance of non-ethical concepts in the correct account of moral phenomena, very much captures the philosophical crux of von Wright's own approach to ethics. Indeed, one of the key theses of The Varieties of Goodness is that there is no separate moral sense of "good", and that the concept of moral goodness should be given an account in terms of non-moral varieties of goodness. ${ }^{40}$ In this sense, von Wright's approach is parallel to the Wittgensteininfluenced approach discussed in the passage: in both, the focus is on families of concepts that are non-ethical but important for philosophical understanding of moral situations and phenomena.

Furthermore, some of von Wright's writings concerning Wittgenstein from the mid 1950s do indicate that the ideal of "Übersichtliche Darstellung" was, in von Wright's view, one of the central methodical keys in understanding Wittgenstein's later philosophy. They also indicate how von Wright tended to understand what such "Übersichtliche Darstellungen" were and what their purpose was. In an article published in the Swedish newspaper Dagens Nyheter on 19 March 1957, von Wright illustrates Wittgenstein's philosophical approach by means of an example concerning a sceptic who doubts the veracity of all his sensory impressions. The Wittgensteinian approach to the question of universal doubt would, according to von Wright, proceed along the following lines:

Let us now $[\ldots]$ ask: Under what 'everyday' conditions do we say that we doubt something? Let us, in other words, investigate the nature and conditions of the non-philosophical doubt before we treat the philosophical question on the possibility and limits of doubt. This should mean to perspicuously describe [Swe. att översiktligt beskriva] the typical (language)situations in which the word "doubt" is in its place. (von Wright 1957a)

Once such "perspicuous description" is undertaken, the universal doubt is revealed as "theoretically senseless" [Swe. teoretiskt

\footnotetext{
${ }^{40}$ See VoG: 1-2, 8, 18, 119, 121-133 and p. 33-34 below. See also Jakola 2014 and 2017 and Österman 2019.
} 
meningslös], and thus the sceptic's "confusion has been healed" [Swe. förvirring är botad] (ibid.). This section of the article does not directly mention Wittgenstein's PI: $\$ 122$ nor the concept of "Übersichtliche Darstellung" - but it seems to me fairly evident that von Wright is referring to this concept and that he understands "Übersichtliche Darstellung" as a perspicuous description ("Übersichtliche Beschreibung") of factual language situations. ${ }^{41}$ And, it seems to me, this is what the first half of The Varieties of Goodness essentially is: a broad and systematic overview of the various uses of the word "good" in language.

\section{2. “... More than a collection of materials for academic controversy"?}

There is also something else that is quite indicative in the same 1957 newspaper article. It is titled "The passion and problem of philosophy" [Swe. Filosofins passion och problem]. Towards the end of the article, von Wright notes that Wittgenstein's later philosophy has greatly influenced the semantic or linguistic philosophy presently (i.e. in the mid 1950s) popular at Oxford. But the reference to these developments also contains a warning. In von Wright's view, some of Wittgenstein's followers often seem to lack the typical "passion" that always characterized Wittgenstein's thought:

What one is often missing in the modern analysts is the problem, an "illness that is to be healed" [Swe. sjukdomen som skall botas]. The danger is that the sharpness of wit is wasted on trifling matters [Swe. petitesser] and that the thought misses the seriousness of "life and death" which makes philosophy relevant for the greater cultural context [Swe. for kulturens större sammanhang]. (von Wright 1957a)

So this is a danger - that philosophy declines into an intelligent but superficial preoccupation with trifling matters, simultaneously losing its relevance for the greater cultural context. Von Wright also definitely implies that, in Wittgenstein's work, this connection was never lost. In fact, the reference to the 'loss of problems' of

\footnotetext{
${ }^{41}$ It is important to see how von Wright might have understood this concept since it is one of the most elusive methodological concepts in Wittgenstein's later thought. For to attribute a significant use (or imitation) of a given concept to some philosopher, one has to have some idea how the philosopher might have understood the concept.
} 
contemporary philosophers also appears in Wittgenstein's writings. Though still unpublished in 1957, it is highly probable that here Wright is alluding to the following remark, now published as $₫ 456$ of Zettel:

Some philosophers (or whatever you like to call them) suffer from what may be called "loss of problems" ["Problemverlust"]. Then everything seems quite simple to them, no deep problems seem to exist any more, the world becomes broad and flat and loses all depth, and what they write becomes immeasurably shallow and trivial. Russell and H. G. Wells suffer from this. (Z: \$456. [MS source: MS 113, 44v, 1932.])

In his 1957 article, von Wright thus connects the idea of 'Problemverlust' with Wittgenstein's other central idea of philosophical problems as intellectual illnesses, which is further connected with philosophy's relevance to the greater cultural context. In fact, this claim brings us back to the starting point of our historical narrative: to von Wright's letter to Wittgenstein from late July 1947. In that letter von Wright claimed that he would always acknowledge his debt to Wittgenstein in making him realize "how difficult philosophy must be, if it is to be more than a collection of materials for academic controversy and learned conversation" (McGuinness, ed., 2008: 414 = item 370). The question is: did von Wright himself succeed in avoiding the intelligent but shallow "trifling matters" in his thought, and is his philosophy more than just a "collection of materials for academic controversy"? Does it have relevance for "the greater cultural context"? I would like to finish this essay off with a few words concerning this question and The $V$ arieties of Goodness.

Prima facie it may, indeed, seem that many passages in The V arieties of Goodness are technical or trivial matters meant mainly for academic controversy. Much in the book, I think, is simply motivated by philosophical curiosity and by a will to map concepts with nothing else but theoretical interest. One may formulate the issue in terms of the rationale of providing 'perspicuous descriptions' in philosophy in the first place. In the case of the sceptic, described above on $\mathrm{p}$. 30, a 'perspicuous description' of language use is undertaken with a clear view to a particular philosophical problem (or 'illness') to be dissolved (or 'healed'). in But in the Varieties, it is not that clear what 
an analogous problem might be. Is the conceptual overview on the varieties of goodness done with some philosophical 'problem' in mind at all? ${ }^{42}$

It seems that one can make a case for the claim that von Wright took the challenge from Wittgenstein seriously and that The Varieties of Goodness does contain an attempt at making analytical philosophy relevant for "the greater cultural context". In his Intellectual Autobiography (written in the early 1970s), von Wright stated that he has felt a disquieting "discrepancy between the narrowly restricted relevance and scope of [his] professional work and the drive which [he] always felt to make philosophy relevant to [his] life and understanding of the world", also calling this discrepancy a "rift" in his philosophical personality. But he also adds that this rift has "begun to heal", and that a "perceptive reader of The Varieties of Goodness" will see what he means. ${ }^{43}$ (von Wright 1989: 18)

One possible way of interpreting this claim is to relate it to two interconnected ideas formulated in Chapter 1 of The Varieties: First, in Section 8, von Wright argues that moral goodness is a derivative form of goodness and is thus not on the same level with the other varieties of goodness. ${ }^{44}$ Second, he views this concept as something "in search of a meaning" ( $V o G: 5)$, suggesting that it may be articulated in different ways in different contexts. His basic idea is that this 'search of a meaning' takes place in the broad conceptual framework constituted by the varieties of goodness and other relevant axiological and psychological concepts that constitute the subject matter of his "broad approach to ethics" (VoG: 6-7). While von Wright's work on the varieties of goodness is mainly descriptive, focussing on dissecting the rule-governed uses of "good" in language, this does not apply as such to the concept of moral goodness. ${ }^{45}$

\footnotetext{
${ }^{42}$ I am grateful to Bernt Österman for having pointed out this difference to me in discussions. His suggestion was that the 'problem' might be the puzzlement concerning the criteria to be used in moral evaluation; my argument in the following paragraphs develops this line of thought.

${ }^{43}$ For an illuminating analysis of how $V o G$ and Explanation and Understanding contributed to the "healing of the rift", see Bernt Österman (2019).

${ }^{44}$ See note 40 above.

${ }^{45}$ See Jakola 2014 for an argument that one ought to distinguish between two levels of analytical work in $V o G$.
} 
Bernt Österman (2019: 6) has recently described von Wright's approach as follows:

The idea is, roughly, that the philosopher "moulds" the meaning of the concepts by determining their logical place within a field of concepts [VoG: 5-6]. In the special case of moral goodness this means that the philosopher specifies a meaning of the notion in a framework provided by non-moral notions of good, or what von Wright calls "the varieties of goodness" [VoG: 18, 119].

To cut a long story short: since various basic varieties of goodness provide conceptual ingredients for articulating a 'moulded' concept of moral goodness, it is the very quest for the criteria of moral evaluation that gives a rationale for von Wright's "perspicuous presentation" of the varieties of goodness. Ultimately, then, his analytical overview of the varieties of goodness aims at "directing our lives" (VoG: 6). One may thus suggest that the problem behind the enterprise is, after all, the age-old practical problem "Was soll ich tun?" 46

Von Wright did not, of course, borrow these systematic ideas of the nature of moral goodness or of moulding analysis from Wittgenstein. Indeed, the idea that a philosopher is entitled to mould concepts probably sounds quite foreign to many readers of Wittgenstein - and I believe legitimately so. It seems, however, that von Wright was aware of this discrepancy. For in his Intellectual Autobiography, he defended his explicative or moulding approach to conceptual analysis in explicit dialogue with Wittgenstein's idea that "philosophy may in no way interfere with the actual use of language" (PI: \$124). His proposal is that it indeed may not - except for there, and only there, where the existing linguistic usage is loose or partly open. ${ }^{47}$ Thus, von Wright characterizes his approach to conceptual analysis as "filling of gaps in (linguistic) usage" (von Wright 1989:

\footnotetext{
${ }^{46}$ Note, however, an important difference with the sceptic, p. 30 above: whereas the sceptic's problem is dissolved by the philosophical overview of language use, the overview of the ethically relevant concepts rather provides the philosopher with a systematic theoretical framework for solving practical questions. Is this another example of how Wittgensteinian ideas transform when integrated into von Wright's own thought?

${ }^{47}$ This seems to presuppose that establishing a usage or making an existent usage more precise is not intervention in the usage. This idea seems quite questionable to me.
} 
49). Returning to his 1963 proposal of 'moulding analysis' he suggests:

[The philosopher's] task is to reflect on the conceptual standards used in moral censuring and social criticism. But this is likely to have practical implications to his life and, to the extent his thoughts are influential, for the lives of others as well. In this way, a philosopher may contribute not only to our understanding of the world - in the light of clarified concepts - but also, indirectly, to changing the world - in consequence of changed practical attitudes (von Wright 1989: 51).

Österman suggests (2019: 6) that von Wright's proposal of 'moulding analysis' in the V arieties of Goodness may be seen as part of von Wright's attempt to make analytic philosophy 'relevant for life'. ${ }^{48}$ This may, in turn, be viewed as an attempt to answer a challenge von Wright acknowledges to have got from Wittgenstein in 1947. If this is so, this also highlights how complex the process of 'assimilation' and 'rejection' of the "Wittgensteinian goods" into von Wright's own systematic thought was: to follow Wittgenstein's example in this sense, meant, for von Wright, also rejecting the Wittgensteinian idea that philosophy must be an exclusively descriptive enterprise.

If the argument in this section has been cogent, we may add yet another item to the list of Wittgensteinian influences present in The $V$ arieties of Goodness. Unlike points I-III (p. 3-4 above), in which one may easily pinpoint clear parallels between von Wright and Wittgenstein, this point is more elusive. It seems to be based more on how Wittgenstein influenced von Wright by his personal example than through his methods or techniques: ${ }^{49}$

IV. Philosophy and its relevance for the greater cultural context. Inspired by Wittgenstein's example, von Wright acknowledged the risk that philosophy all too easily becomes trivial and superficial (compare Z: \456). In The V arieties of Goodness, he argued that philosophical

\footnotetext{
${ }^{48}$ See also Österman's (2019, 7n15) argument that von Wright's proposal is connected with Wittgenstein's $(1994,53)$ dictum that "Die Arbeit an der Philosophie ist [...] eigentlich mehr die Arbeit an Einem selbst".

${ }^{49}$ Compare von Wright (1982: 11), where he states that Wittgenstein influenced his "intellectual development" more by "example" than by his "teaching and writing".
} 
analysis in ethics also aims at directing our lives ( $V o G$ : 6) by 'moulding' the conceptual framework used in moral evaluation.

\section{Concluding remarks: Assimilation and rejection}

In this article, I have traced two parallel and intertwined lines of development in von Wright's intellectual development from 1947 to 1963: that of his value theory and the slow and complex process of integrative 'assimilation' and 'rejection' of influences stemming from Wittgenstein's later philosophy. Even though von Wright's interest in ethics and in Wittgenstein's later thought were originally independent, still they meet in the early 1950s as von Wright encounters problems applying his Q-logic in the analysis of axiological concepts and, simultaneously, is disappointed with his first attempts at giving a descriptive overview of Wittgenstein's later philosophy. Thus, we find him, in 1954, applying demonstrably lateWittgensteinian ideas in a novel analysis concerning the possibility of the truth of value-statements. Some of the Wittgensteinian ideas which seemed initially assimilated in 1954 are, however, eventually partly rejected or given a quite distinct twist in von Wright's own systematic work. The whole perspective also widens from the 1954 investigation of value-judgments via von Wright's lectures in the late 1950s to the 1963 comprehensive study of the varieties of goodness. But, as I have indicated, there are some indications that in the late 1950s new connections to Wittgenstein emerge: the aim of a 'perspicuous description' of the grammar of "good" and an attempt to make analytical work relevant for the greater cultural context.

I hope that this article has also made clear the merit of investigating the emergence of Wittgenstein's influences in von Wright's philosophy historically. For by studying The Varieties of Goodness alone, it may well be illuminating to speculate about the possible Wittgensteinian origins of some given ideals, techniques, or distinctions (cf. points I-III in Section 1 above and point IV in Section 5.2), but due to the lack of direct references on the one hand and due to these influences having been, by the early 1960s, integrated firmly into von Wright's own constructive philosophy on the other, it is seldom possible to confirm them. By having a look at 
earlier, partly unpublished materials and by studying von Wright's philosophy of goodness historically, it is, in contrast, often possible to confirm the influences and to pinpoint exact references to, parallels with, and imitations of Wittgenstein's later work. ${ }^{50}$

\section{References}

\section{A. Published primary and secondary sources:}

Anscombe, E., 1958. "Modern Moral Philosophy". Philosopby 33, 1-19.

Baker, G., 2004. Wittgenstein's Method. Neglected Aspects. Essays on Wittgenstein by Gordon Baker. Edited and introduced by K. J. Morris. Oxford: Blackwell.

Baker, G. and P. M. S. Hacker, 2005. Wittgenstein. Understanding and Meaning. Volume 1 of an Analytical Commentary on the Philosophical Investigations. Part I - Essays. Oxford: Blackwell.

Broad, C. D., 1944. "Hr. Von Wright on the Logic of Induction I-III". Mind 53, 11-24; 97-119; 193-214.

Erbacher, C., 2016. "Wittgenstein and His Literary Executors". Journal for the History of Analytical Philosophy 4, No. 3, 1-39.

Foot, P., 1958. "Moral Arguments". Mind 67, 502-513.

Geach, P. 1958. "Good and Evil". Analysis 17, 33-42.

Hacker, P. M. S., 1996. Wittgenstein's Place in Twentieth-Century Analytic Philosophy. Oxford, Blackwell.

Helsingin Yliopiston Objelma. Helsinki: Helsingin yliopisto, 1943-1962.

Heyl, B. C., 1943. New Bearings in Esthetics and Art Criticism. New Haven: Yale University Press.

Hägerström, A., 1911. Om moraliska föreställningars sanning. Stockholm: Bonniers.

Jakola, L., 2014. "Hyvän muunnelmat, analyysin muunnelmat: G. H. von Wright moraalisen byvän luonteesta". In: N. Hämäläinen, J. Lemetti and

\footnotetext{
${ }^{50} \mathrm{I}$ am indebted to the two anonymous reviewers whose suggestions essentially improved many sections of this article. I also thank Alberto Emiliani and Peter Hacker for comments, the participants of Prof. Thomas Wallgren's von Wright and Wittgenstein seminar at the University of Helsinki for discussions, and Robert Whiting for having brushed up my English. Finally, thanks are due to Anita von Wright-Grönberg and Benedict von Wright for allowing me to quote from $G$. H. von Wright's unpublished scientific correspondence and manuscripts, and to Eero Kaila, who gave me access to the minutes of the Finnish Philosophical Society.
} 
I. Niiniluoto, eds., Hyve. Philosophical Studies from the University of Helsinki 45. Helsinki: Helsingin yliopisto, 107-122.

Jakola, L. 2017. 'In Search of 'the Good of Man': Georg Henrik von Wright's Humanistic Ethics". In I. Niiniluoto and T. Wallgren, eds., On the Human Condition: Philosophical Essays in Honour of the Centennial Anniversary of Georg Henrik von Wright. Acta Philosophica Fennica 93, 269-290.

Jakola, L. 2020. "Von Wright and Wittgenstein on (the Varieties of) Goodness and Family Resemblance: A Constructive Rejoinder to Klagge (2018)". Philosophical Investigations. 43, 301-333. DOI: 10.1111/phin.12250

Kenny, A., 2005. “A Brief History of Wittgenstein Editing”. In: A. Pichler and S. Säätelä, eds., Wittgenstein. The Philosopher and his Works. Bergen: WAB, 341-355.

Klagge, J. C. (2018). "Wittgenstein and von Wright on Goodness". Philosophical Investigations 41, 291-303.

Kruskopf, E. (ed.) 2008. En livsläng vänskap. Brevväxling mellan Göran Schildt och Georg Henrik von Wright 1937-2001. Ekenäs: Christine och Göran Schildts Stiftelse.

Langer, S., 1941. Philosopby in a New Key. A Study in the Symbolism of Reason, Rite and Art. Harvard: Harvard University Press.

Lindfors, P., 1992. "Eino Kaila and the Scientific Weltauffassung". In: I. Niiniluoto, M. Sintonen, and G. H. von Wright, eds., Eino Kaila and Logical Empiricism. Helsinki: Acta Philosophica Fennica, 92-101.

McGuinness, B., ed., 2008. Wittgenstein in Cambridge: Letters and Documents, 1911-1951. $4^{\text {th }}$ ed. Malden, MA: Blackwell.

Moore, G. E., 1966 [1903]. Principia Ethica. Cambridge: Cambridge University Press.

Österman, B., 2014. "Spåret efter The V arieties of Goodness - en jämförelse av värdefilosofin hos Georg Henrik von Wright och Judith Jarvis Thomson”. In: N. Hämäläinen, J. Lemetti, and I. Niiniluoto (eds.), 2014. Hyve. Helsinki: Helsingin yliopiston filosofian laitoksen julkaisuja, 123-132.

Österman, B., 2017. "'Jag kan inte låta bli att oupphörligt jämföra honom med Cézanne’. Hur Göran Schildt hjälpte Georg Henrik von Wright att lösa problemet Ludwig Wittgenstein”. Finsk Tidskrift 7/2017, 5165.

Österman, B., 2019. "Healing the Rift: How G. H. von Wright Made Philosophy Relevant to His Life". Journal for the History of Analytical Philosophy 7, no 8, 1-19.

Salmela, M., 2003. “Analytic Moral Philosophy in Finland”. In: L. Haaparanta and I. Niiniluoto, eds., Analytic Philosopby in Finland. 
(Poznan Studies in the Philosophy of the Sciences and the Humanities, vol. 80.) Amsterdam: Rodopi, 414-444.

Urmson, J. O., 1968. The Emotive Theory of Ethics. London: Hutchinson \& CO. Wellman, C., 1976. “The Meaning of 'Good”'. In: J. Hintikka, ed., Essays on Wittgenstein in Honour of G. H. von Wright. (Acta Philosophica Fennica, Vol. 28, Nos. 1 - 3). Amsterdam: North-Holland 394-416.

Williams, B., 2006 [1985]. Ethics and the Limits of Philosophy. Abdington: Routledge.

Wittgenstein, L., 1967. Zettel. Ed. G. E. M. Anscombe and G. H. von Wright. Oxford: Basil Blackwell.

Wittgenstein, L., 1968 [1953]. Philosophical Investigations: Philosophische

Untersuchungen. 3. ed., repr. Oxford: Blackwell.

Wittgenstein, L., 1971 [1922]. Tractatus Logico-philosophicus. London: Routledge \& Kegan Paul.

Wittgenstein, L., 1972 [1958]. The Blue and the Brown Books. Oxford: Basil Blackwell.

Wittgenstein, L., 1994 [1977]. Vermischte Bemerkungen. Eine Auswabl aus dem Nachlaß. Herausgegeben von G. H. von Wright unter Mitarbeit von H. Nyman. Neubearbeitung des Textes durch A. Pichler. Frankfurt a. M.: Suhrkamp.

von Wright, G. H., 1940. “On Probability”. Mind 49, 265-283.

von Wright, G. H., 1941. The Logical Problem of Induction. Helsinki: Acta Philosophica Fennica.

von Wright, G. H., 1948. "On the Idea of Logical Truth. I". Helsingfors: Societas Scientiarum Fennica. Commentationes PhysicoMathematicae. Vol. 14.

von Wright, G. H., 1950. “On the Idea of Logical Truth. II”. Helsingfors:

Societas Scientiarum Fennica. Commentationes Physico-

Mathematicae. Vol. 15.

von Wright, G. H., 1951a. An Essay in Modal Logic. Amsterdam: NorthHolland.

von Wright, G. H., 1951b. Deontic Logic. Edinburgh: Nelson.

von Wright, G. H., 1952. "On the logic of some axiological and epistemological concepts”. Ajatus 17, 213-234.

von Wright, G. H., 1954. "Om moraliska föreställningars sanning”. Nordisk Sommer Universitet 1953: Vetenskapens Funktion i Sambället. København: Munksgaard, 48-74.

von Wright, G. H., 1957a. "Filosofins passion och problem." Dagens Nyheter 19 March 1957.

von Wright, G. H., 1957b. Logik, filosofi och språk: strömningar och gestalter $i$ modern filosofi. Helsingfors: Söderström.

von Wright, G. H., 1963a. The Logic of Preference: An Essay. Edinburgh: University Press. 
von Wright, G. H., 1963b. The V arieties of Goodness. London: Routledge \& Kegan Paul.

von Wright, G. H., 1963c. Norm and Action: A Logical Enquiry. London:

Routledge \& Kegan Paul.

von Wright, G. H., 1971. Explanation and Understanding. Ithaca, NY: Cornell University Press.

von Wright, G. H., 1982. Wittgenstein. Oxford: Blackwell.

von Wright, G. H., 1989. "Intellectual Autobiography”. In: L. E. Hahn and

P. A. Schilpp, ed., The Philosophy of Georg Henrik von Wright. La Salle

(IL): Open Court, 3-55.

von Wright, G. H., 1998. In the Shadow of Descartes. Dordrecht: Kluwer

Academic Publishers.

von Wright, G. H., 1999. Tieto ja ymmärrys. Helsinki: Otava.

von Wright, G. H., 2001. Mitt liv som jag minns det. Helsingfors: Söderström \& Co. Förlags Ab.

\section{B. Unpublished sources and archival materials:}

The National Library of Finland (NLF):

von Wright, G. H. and E. Anscombe. The scientific correspondence between

G. H. von Wright and Elizabeth Anscombe. COLL. 714, 11-12.

National Library, University of Helsinki.

von Wright, G. H. and P. Geach. The scientific correspondence between G.

H. von Wright and Peter Geach. COLL. 714, 71-72. National Library, University of Helsinki.

Von Wright and Wittgenstein Archives (University of Helsinki) (WW A):

von Wright, G. H., (UP1). "Förteckning över Tentander samt Deltagare i

Föreläsningar och Övningar (_1966)”. Unpublished hand-written notebook.

von Wright, G. H., (UP2). "Luonnokset käyt. fil. luentoihin Helsingin yliopistossa 1953-1959”. Unpublished Manuscript.

von Wright, G. H., (UP3). " 2 nd and $3^{\text {rd }}$ version of The Varieties of Goodness” (1959-1960). Unpublished Manuscript.

von Wright, G. H., (UP4). "Wittgenstein om frågan om språkets väsen" (1953). Unpublished Manuscript.

The Philosophical Society of Finland

Suomen filosofisen yhdistyksen pöytäkirjat 1952. Minutes concerning the gatherings of The Philosophical Society of Finland on 24 Sept and 29 October 1952. Retrieved per email from Eero Kaila on 20 December 2018 and 11 February 2019. 


\section{Biographical note}

Lassi Jakola is a doctoral student in Classics and Philosophy at the University of Helsinki. His research focuses on the sophistic movement ( $5^{\text {th }}$ century BCE) and on G. H. von Wright's philosophy of values. Presently, he is employed in the projects The Creation of Wittgenstein and Den okände von Wright at the University of Helsinki, financed by the Academy of Finland and the Society of Swedish Literature in Finland. 